\title{
Pulmonary Hypertension Is Associated with Mortality and Cardiovascular Events in Chronic Kidney Disease Patients
}

\author{
Javier Reque ${ }^{a} \quad$ Ana Garcia-Prieto $^{a} \quad$ Tania Linares $^{a} \quad$ Almudena Vega ${ }^{a}$ \\ Soraya Abad ${ }^{a}$ Nayara Panizo ${ }^{a}$ Borja Quiroga $^{a}$ Eladio J. Collado Boira ${ }^{b}$ \\ Juan Manuel López-Gómez ${ }^{\mathrm{a}}$ \\ ${ }^{a}$ Department of Nephrology, Hospital General Universitario Gregorio Marañón, Madrid, and ${ }^{\text {b}}$ Faculty of Health \\ Sciences, University Jaime I, Castellon, Spain
}

\section{Key Words}

Pulmonary hypertension · Haemodialysis · Fluid overload .

Cardiovascular risk - Outcomes

\begin{abstract}
Background: We evaluated the prevalence, determinants and prognosis value of pulmonary hypertension $(\mathrm{PH})$ in nondialysis chronic kidney disease (CKD) patients. Methods: This is a prospective study with stages 3-5 non-dialysis-dependent CKD patients. PH was estimated by Doppler echocardiography and defined as a pulmonary artery systolic pressure above $35 \mathrm{~mm} \mathrm{Hg}$. Results: Three hundred fifty-three patients were recruited, of whom 94 (26.6\%) had PH. Prevalence of $\mathrm{PH}$ increased with the decline of renal function: 21.6, 24.1, and $31.7 \%$ in stages 3, 4, and 5, respectively. Independent predictors of $\mathrm{PH}$ were age, estimated glomerular filtration rate (eGFR), history of cardiovascular (CV) events, the presence of an arteriovenous fistulae (AVF), and left ventricular (systolic and diastolic) dysfunction. Over a median follow-up of 22 months, 71 patients died (20\%). After multivariate adjustment for age, gender, previous CV disease, diastolic and systolic dysfunction, $\mathrm{PH}$ remained as an independent predictor of all-cause mortality (hazards ratio [HR] 1.84, 95\% Cl $1.06-3.18, p=0.02)$. One hundred patients (28\%) had a new onset CV event. After adjustment for age, gender, previous
\end{abstract}

$\mathrm{CV}$ disease, systolic and diastolic dysfunction, $\mathrm{PH}$ maintains its independent association with CV events (HR $2.77,95 \% \mathrm{Cl}$ 2.00-3.25, $p<0.001)$. Conclusions: $\mathrm{PH}$ prevalence rises as kidney function declines. Main determinants of $\mathrm{PH}$ are age, eGFR, previous CV disease, the presence of an AVF and left ventricular systolic or diastolic dysfunction. $\mathrm{PH}$ is an independent predictor of all-cause mortality and CV events.

(c) 2016 S. Karger AG, Basel

\section{Introduction}

In recent years, pulmonary hypertension $(\mathrm{PH})$ in chronic kidney disease (CKD) patients is gaining interest because of its apparent high prevalence and its significant role in the outcome, principally in patients undergoing hemodialysis (HD) [1-3]. This condition usually remains asymptomatic and sometimes is misdiagnosed over a period of time until right ventricular dysfunction begins to manifest by worsening fatigue, dyspnea and syncope [4]. Recent studies suggest a higher prevalence of this entity in stage 5 non-dialysis dependent CKD patients $[5,6]$, HD patients $[2,7,8]$ and peritoneal dialysis patients $[9$, 10] compared to healthy individuals. A recently published paper has included stages 1-4 CKD patients and evaluated the outcomes [11].

\section{KARGER}

(c) 2016 S. Karger AG, Basel

E-Mail karger@karger.com

www.karger.com/ajn
Javier Reque

Department of Nephrology

Hospital General Universitario Gregorio Marañón, C/Doctor Esquerdo

46, ES-28007 Madrid (Spain)

E-Mail javier.reque@ hotmail.com 
The gold standard for the diagnostic of $\mathrm{PH}$ is right heart catheterization (RHC) $[4,12]$. Based on this procedure, $\mathrm{PH}$ is defined as a mean pulmonary arterial pressure above $25 \mathrm{~mm} \mathrm{Hg}$ at rest [12]. RHC is an invasive, costly, risky and poorly accessible test, so transthoracic echocardiography is recommended for $\mathrm{PH}$ screening [13]. A good correlation has been found between both techniques $[14,15]$. Although it is possible to estimate the mean pulmonary arterial pressure by 2D Doppler echocardiography, most studies often report the pulmonary artery systolic pressure (PASP) because of its accuracy $[16,17]$.

The aims of this study are to analyze the prevalence of $\mathrm{PH}$ in CKD patients and to elucidate the risk factors associated with $\mathrm{PH}$ and its prognosis value on mortality and cardiovascular (CV) events.

\section{Methods}

\section{Patients}

We conducted a prospective study, including stages 3-5 nondialysis-dependent CKD patients from a single center in Madrid. CKD was defined and evaluated according to the Kidney Disease Outcomes Quality Initiative guidelines and using the Modification of Diet in Renal Disease equation [18]. Inclusion criteria were age $\geq 18$ years, CKD stages $3-5$ non-dialysis dependent, outpatient follow-up for at least 3 months, clinical stability (defined as no need for hospitalization or emergency care within 3 months prior to the inclusion). Exclusion criteria were clinical instability, inability to understand the study or rejection to personal data record and processing, poor echocardiography quality or PASP not correctly reported. All procedures were performed according to the Helsinki Declaration and its revisions. All patients gave consent for participation in the study and data processing. Demographic and clinical data on parameters such as age, gender, etiology of CKD (identified by clinical features and confirmed primarily by biopsy), diabetes mellitus, hypertension (as defined by the Eight Report of the Joint National Committee [19]), history of previous CV disease including congestive heart failure (CHF), myocardial infarction, peripheral vascular disease, and stroke were collected.

\section{Laboratory Tests}

Laboratory parameters were routine tests, inflammation and nutrition parameters including albumin, high sensitivity C-reactive protein (hs-CRP), and cardiac biomarkers including amino terminal fragment of brain natriuretic peptide (NT-pro-BNP), high sensitivity $\mathrm{T}$ troponin (hs-TnT) and MB isoenzyme of creatine phosphokinase. All measurements were performed according to standard methods.

\section{Echocardiographic Measurements}

We performed a two-dimensional, M-mode and Doppler echocardiogram in the outpatient setting. The estimation of PASP by echocardiography is based on the modified Bernoulli equation as follows [20]: PASP $=4 \times(\mathrm{TRV})^{2}+\mathrm{RAP}$. Where TRV is the maximum tricuspid regurgitation jet speed and RAP is the right atrium pressure, which is estimated by inferior vena cava diameter according to the recommendations of the American Society of Echocardiography [21]. The upper normal limit is usually set between 30 and $35 \mathrm{~mm} \mathrm{Hg}$ on the basis of a large population study [22]. $\mathrm{PH}$ was defined as a PASP value above $35 \mathrm{~mm} \mathrm{Hg}$. We considered severe $\mathrm{PH}$ when PASP was above $55 \mathrm{~mm} \mathrm{Hg}$. Systolic dysfunction was defined as left ventricular ejection fraction below $45 \%$ and diastolic dysfunction according to the echocardiographic parameters of the American Heart Association guidelines [23, 24]. We defined left ventricular hypertrophy as a left ventricular mass index above $130 \mathrm{~g} / \mathrm{m}^{2}$ (males) and $105 \mathrm{~g} / \mathrm{m}^{2}$ (women). The left ventricular mass was estimated using the Devereux formula [25].

\section{Follow-Up and Outcomes Definitions}

During a median follow-up period of 22 (3-49) months, new onset CV events were recorded. These events included ischemic or hemorrhagic cerebrovascular accident, myocardial infarction (diagnosed by cardiac marker elevation and electrocardiography), $\mathrm{CHF}$ and peripheral vascular events. We also recorded all-cause mortality during the follow-up period.

\section{Statistical Analyses}

All variables were analyzed using a Kolmogorov-Smirnov test to classify them as normally or non-normally distributed. Values were given as mean (SD) or median (interquartile range). Categorical data were compared using a chi-square test, while continuous variables were compared using a Student's $t$ test or a Mann-Whitney U test. The mean PASP and PH prevalence between CKD stages was compared by using an analysis of variance. Univariate analysis was performed using logistic regression to assess factors associated with $\mathrm{PH}$. The prognosis value of $\mathrm{PH}$ for predicting the study outcomes was assessed by the Kaplan-Meier analysis (survival curves were compared using a log-rank test) and Cox regression. In multivariate Cox models, we included all variables that showed significant association to the study outcomes at univariate Cox analyses. The models also included those considered confounders factors. All statistical analyses were performed with the SPSS $20.0^{\circledR}$ statistical package (SPSS, Inc., Chicago, IL, USA). Differences were considered statistically significant when $p$ value was $<0.05$.

\section{Results}

\section{PH and Baseline Data}

The initial screening included 531 patients, of which 159 were excluded because PASP not correctly reported and also because of the absence of tricuspid regurgitation or poor acoustic window. The final study analysis was performed in 353 patients. The characteristics of this population are described in Table 1 . Thirty-seven (10.5\%) were in CKD stage 3, 187 (53\%) in stage 4 and 129 (36.5\%) in stage 5 non-dialysis dependent. The prevalence of $\mathrm{PH}$ was $26.6 \%$ (94 patients) and $6.5 \%$ of the population presented severe PH (PASP $>55 \mathrm{~mm} \mathrm{Hg}$ ). The mean PASP in the whole group was $28 \pm 12.4 \mathrm{~mm} \mathrm{Hg}$, while in the $\mathrm{PH}$ group it was $46 \pm 10.8 \mathrm{~mm} \mathrm{Hg}$. The prevalence of $\mathrm{PH}$ in- 
Table 1. Clinical characteristics of the study population. Patients divided based on the presence of $\mathrm{PH}$

\begin{tabular}{|c|c|c|c|c|}
\hline & All & $\mathrm{PH}$ (present) & PH (absent) & $p$ value \\
\hline Patients & $353(100)$ & $94(26.6)$ & $259(73.4)$ & \\
\hline Gender, male & $193(54.7)$ & $49(52.1)$ & $144(55.5)$ & 0.6 \\
\hline Age, years & $67 \pm 13$ & $72 \pm 11$ & $64 \pm 14$ & $<0.001$ \\
\hline Body mass index, $\mathrm{kg} / \mathrm{m}^{2}$ & $27.2 \pm 4.2$ & $27.1 \pm 4.6$ & $27.4 \pm 4.2$ & 0.3 \\
\hline Hypertension & $230(65.1)$ & $67(71.2)$ & $163(63)$ & 0.09 \\
\hline Diabetes mellitus & $154(43.6)$ & $44(46.8)$ & $110(42.5)$ & 0.08 \\
\hline Obstructive sleep apnea & $12(3.4)$ & $4(4.2)$ & $8(3.1)$ & 0.07 \\
\hline \multicolumn{5}{|l|}{ Etiology of ESKD } \\
\hline Diabetes mellitus & $82(23.2)$ & $22(24.4)$ & $60(23.1)$ & 0.3 \\
\hline Hypertension & $90(25.5)$ & $23(24.5)$ & $67(25.8)$ & 0.4 \\
\hline Glomerulonephritis & $76(21.5)$ & $19(20.2)$ & $57(22)$ & 0.3 \\
\hline Interstitial & $40(11.3)$ & $10(10.6)$ & $30(11.6)$ & 0.3 \\
\hline Diastolic blood pressure, $\mathrm{mm} \mathrm{Hg}$ & $82 \pm 16$ & $80 \pm 15$ & $83 \pm 17$ & 0.4 \\
\hline \multicolumn{5}{|l|}{ History of smoking } \\
\hline Current & $65(18.4)$ & $18(19.1)$ & $47(18.1)$ & 0.2 \\
\hline Past & $87(24.6)$ & $27(28.7)$ & $60(23.1)$ & 0.09 \\
\hline Previous CV disease & $95(26.9)$ & $33(35.1)$ & $62(23.9)$ & 0.001 \\
\hline Albumin, g/dL & $4.3 \pm 0.2$ & $4.1 \pm 0.3$ & $4.4 \pm 0.2$ & 0.7 \\
\hline C-reactive protein, $\mathrm{mg} / \mathrm{dL}$ & $0.7(0.24-0.98)$ & $1.2(0.6-2.1)$ & $0.6(0.24-1.1)$ & 0.04 \\
\hline NT-Pro-BNP, ng/L & $45(28-200)$ & $209(98-457)$ & $33(28-38)$ & $<0.001$ \\
\hline Hs-TnT, ng/L & $50(10-128)$ & $64(12-152)$ & $40(10-98)$ & 0.001 \\
\hline Calcium, mg/dL & $9.4 \pm 0.6$ & $9.5 \pm 0.6$ & $9.4 \pm 0.6$ & 0.4 \\
\hline Phosphorus, mg/dL & $4.6 \pm 0.9$ & $5.5 \pm 0.8$ & $4.4 \pm 0.7$ & 0.04 \\
\hline Parathyroid hormone, mg/dL & $120(85-150)$ & $156(82-325)$ & $98(72-125)$ & 0.001 \\
\hline Epoetin & $36(13.5)$ & $14(14.8)$ & $32(12.3)$ & 0.09 \\
\hline
\end{tabular}

Data are given as mean $\pm \mathrm{SD}$, median (interquartile range) or numbers and percent frequency as appropriate.

Bold values in this table represent those that reached statistical significance.

ESKD, end-stage kidney disease; GFR, glomerular filtration rate; CV, cardiovascular; $\mathrm{PH}$, pulmonary hypertension.

creases with the severity of CKD as seen in Table 2. Data analysis according to the presence or absence of $\mathrm{PH}$ showed that patients with $\mathrm{PH}$ were significantly older, with worse kidney function, higher hs-CRP, NtProBNP, hs-TnT and PTH levels. They were more frequently affected by previous CV disease. Systolic and diastolic dysfunctions were more frequent among patients with $\mathrm{PH}$. All these differences are detailed in Table 1. Independent predictors of $\mathrm{PH}$ were age, estimated glomerular filtra- tion rate (eGFR), history of $\mathrm{CV}$ events, presence of an arteriovenous fistulae (AVF), systolic and diastolic dysfunction as shown in Table 3.

\section{PH and Risk of Death}

During a median follow-up period of 22 (3-49) months, 71 patients died (20\%), 27 in the non- $\mathrm{PH}$ group $(16.9 \%)$ and 44 in the $\mathrm{PH}$ group $(28.7 \%$; $p<0.001)$. The main causes of death were CV (44.1\%), followed by in- 
Table 2. $\mathrm{PH}$ at different $\mathrm{CKD}$ stages

\begin{tabular}{lccccc}
\hline & All & Stage 3 & Stage 4 & Stage 5 & $p$ value \\
\hline Patients & $353(100)$ & $37(10.5)$ & $187(53)$ & $129(36.5)$ & \\
PH prevalence & $94(26.6)$ & $8(21.6)$ & $45(24.1)$ & $41(31.7)$ & 0.01 \\
Mild PH: $35-55 \mathrm{~mm} \mathrm{Hg}$ & $71(20.1)$ & $7(18.9)$ & $33(17.6)$ & $31(24)$ & 0.01 \\
Severe PH: $>55 \mathrm{~mm} \mathrm{Hg}$ & $23(6.5)$ & $1(2.7)$ & $12(6.5)$ & $10(7.7)$ & 0.01 \\
PASP, $\mathrm{mm} \mathrm{Hg}$ & $28 \pm 12$ & $27 \pm 11$ & $28 \pm 12$ & $29 \pm 13$ & 0.4 \\
Mean eGFR, $\mathrm{mL} / \mathrm{min} / 1.73 \mathrm{~m}^{2}$ & $18.9 \pm 8.1$ & $43 \pm 6$ & $23 \pm 3$ & $9 \pm 2$ & 0.01 \\
\hline
\end{tabular}

Data are expressed as mean $\pm \mathrm{SD}$, or percent frequency as appropriate.

eGFR, estimated glomerular filtration rate; PH, pulmonary hypertension; PASP, pulmonary artery systolic pressure.

Table 3. Logistic regression analyses for variables associated with $\mathrm{PH}$

\begin{tabular}{|c|c|c|c|c|}
\hline & \multicolumn{2}{|l|}{ Unadjusted } & \multicolumn{2}{|l|}{ Adjusted $^{\mathrm{a}}$} \\
\hline & HR $(95 \% \mathrm{CI})$ & $p$ value & $\operatorname{HR}(95 \% \mathrm{CI})$ & $p$ value \\
\hline Age (1 year) & $1.03(1.01-1.04)$ & $<0.001$ & $1.05(1.01-1.08)$ & 0.03 \\
\hline Estimated GFR $\left(1 \mathrm{~mL} / \mathrm{min} / \mathrm{m}^{2}\right)$ & $1.02(1.01-1.04)$ & 0.04 & $1.04(1.02-1.08)$ & 0.04 \\
\hline Previous CV disease & $4.26(1.06-11.24)$ & 0.01 & $2.39(1.94-2.39)$ & 0.01 \\
\hline C-reactive protein $(1 \mu \mathrm{g} / \mathrm{dL})$ & $1.09(1.05-1.88)$ & 0.04 & $1.01(0.89-1.23)$ & 0.06 \\
\hline Parathyroid hormone $(1 \mathrm{mg} / \mathrm{dL})$ & $1.07(1.05-2.01)$ & 0.01 & $1.01(0.79-1.86)$ & 0.08 \\
\hline Arteriovenous fistulae & $2.45(1.86-3.12)$ & 0.04 & $2.01(1.51-2.10)$ & 0.02 \\
\hline Systolic dysfunction & $3.14(2.85-3.55)$ & $<0.001$ & $3.07(1.75-3.56)$ & 0.01 \\
\hline Diastolic dysfunction & $2.96(2.69-3.51)$ & 0.01 & $2.28(1.29-2.81)$ & 0.02 \\
\hline
\end{tabular}

${ }^{a}$ Multivariate model included all variables that were associated with $\mathrm{PH}$ at univariate analyses.

GFR, glomerular filtration rate; CV, cardiovascular.

fections (26.1\%) and malignancy (20\%). The relative risk of mortality was higher in patients with $\mathrm{PH}$ (hazards ratio [HR] 3.14, 95\% CI 1.53-4.95, $p \leq 0.001$ ). In a Kaplan-Meier survival analysis, the risk of all-cause mortality is higher in patients with PH (Fig. 1). In the multivariate Cox model, $\mathrm{PH}$ remained as an independent predictor. Apart from $\mathrm{PH}$, the independent variables increasing the risk of mortality were age, previous $\mathrm{CV}$ disease, systolic and diastolic dysfunction, as shown in Table 4.

\section{Events}

During the follow-up, it was found that there was new onset of CV events in 100 patients (28\%) - 45 (47.8\%) events in the $\mathrm{PH}$ group and $55(21.2 \%)$ in the non-PH group $(p<0.001)$. The most common CV event was heart failure (24.8\%) followed by stroke (20.2\%) and cardiac arrest (12.4\%). The Kaplan-Meier estimation of CV events, shown in Figure 2, demonstrate a higher risk of CV events among patients with $\mathrm{PH}$. Again, the independently pre- dictive value of $\mathrm{PH}$ for $\mathrm{CV}$ events was confirmed by the multivariate Cox model (HR 2.52, 95\% CI 1.96-2.56, $p=$ 0.01 ) as shown in Table 4.

\section{Discussion}

Our study supported the results of previous investigators who found that the prevalence among CKD patients was high. Moreover, we confirm that this prevalence rises as the kidney function declines. The main predictors of $\mathrm{PH}$ in CKD patients stages 3-5 are, age, eGFR, history of $\mathrm{CV}$ events, the presence of AVF, systolic and diastolic dysfunction. We also found a worse prognosis of this population group when diagnosed with $\mathrm{PH}$, this entity being an independent predictor of mortality and $\mathrm{CV}$ events.

Two large population-based studies had analyzed the prevalence of $\mathrm{PH}$ in general population and found that it was between 5 and 9.1\% [22,26]. Our study showed a prev- 


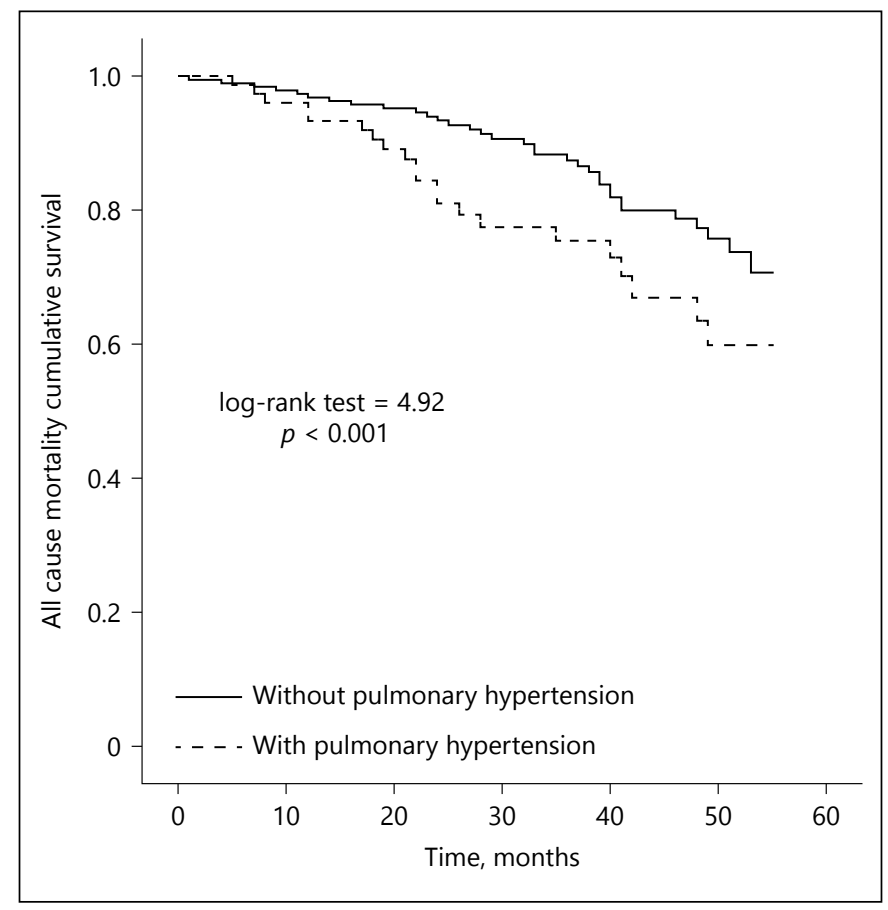

Fig. 1. Kaplan-Meier cumulative survival curve for all-cause mortality.

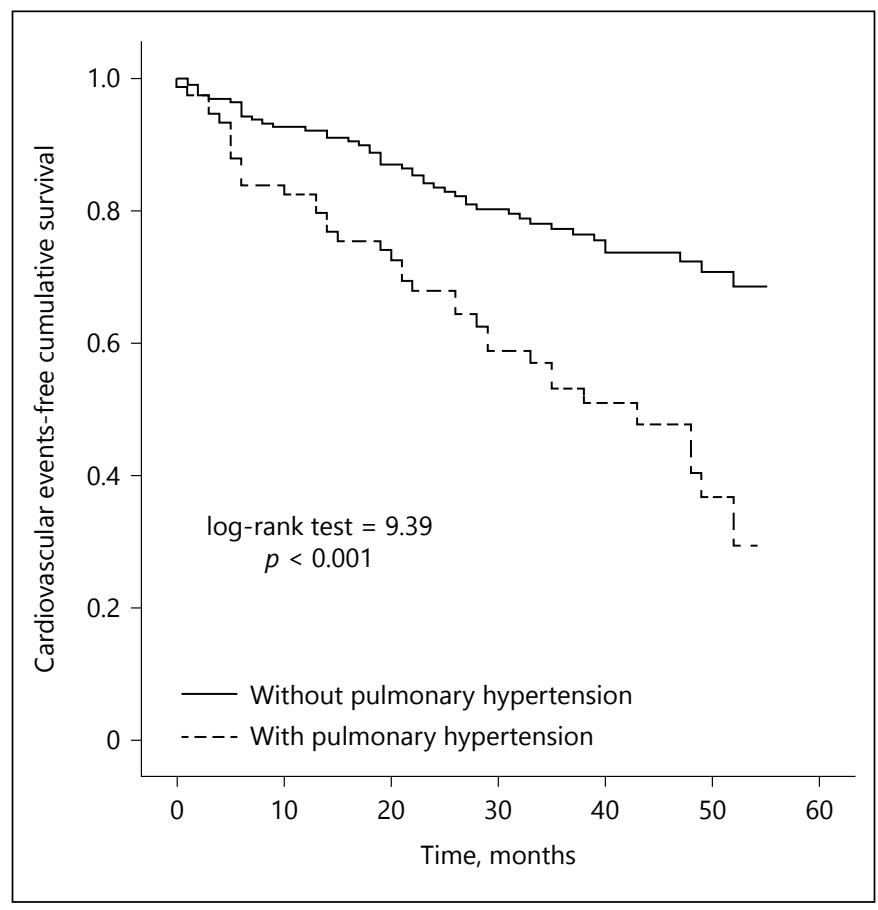

Fig. 2. Kaplan-Meier cumulative survival curve for CV events.

Table 4. Crude and adjusted Cox regression analyses for all-cause mortality and CV events

\begin{tabular}{|c|c|c|c|c|}
\hline & \multicolumn{2}{|l|}{ Unadjusted } & \multicolumn{2}{|l|}{ Adjusted $^{\mathrm{a}}$} \\
\hline & HR (95\% CI) & $p$ value & HR (95\% CI) & $p$ value \\
\hline \multicolumn{5}{|l|}{$C V$ events } \\
\hline Age, years & $1.04(1.01-1.06)$ & 0.01 & $1.03(1.01-1.04)$ & 0.04 \\
\hline Previous CV disease & $4.96(4.03-13.08)$ & $<0.001$ & $4.05(2.17-7.13)$ & $<0.001$ \\
\hline Diabetes mellitus & $1.98(1.25-2.76)$ & 0.01 & $1.23(1.12-1.65)$ & 0.04 \\
\hline $\mathrm{PH}$ & $3.02(1.66-5.50)$ & $<0.001$ & $2.52(1.95-5.56)$ & 0.01 \\
\hline Diastolic dysfunction & $4.41(2.37-7.25)$ & $<0.001$ & $1.82(1.21-2.95)$ & 0.02 \\
\hline Systolic dysfunction & $2.25(1.26-4.00)$ & 0.04 & $1.08(0.98-2.92)$ & 0.06 \\
\hline \multicolumn{5}{|l|}{ All cause mortality } \\
\hline Age, years & $1.02(1.00-1.04)$ & 0.03 & $1.16(1.03-1.14)$ & 0.03 \\
\hline Previous CV disease & $2.09(1.38-3.09)$ & $<0.001$ & $1.52(1.05-2.53)$ & 0.02 \\
\hline C-reactive protein & $1.23(1.09-1.35)$ & $<0.001$ & $1.09(0.98-1.10)$ & 0.06 \\
\hline $\mathrm{PH}$ & $3.14(1.53-4.95)$ & $<0.001$ & $1.74(1.16-3.08)$ & 0.02 \\
\hline Diastolic dysfunction & $3.25(2.13-5.89)$ & $<0.001$ & $1.71(1.09-1.94)$ & 0.02 \\
\hline Systolic dysfunction & $2.15(1.25-2.60)$ & 0.01 & $1.22(1.12-1.29)$ & 0.03 \\
\hline
\end{tabular}

${ }^{a}$ Multivariate model included all variables that were associated with study outcomes at univariate analyses.

alence of $26.6 \%$ in patients with CKD stages 3-5 non dialysis dependent. Similar findings were reported by a recent study that included $468 \mathrm{CKD}$ patients where the prevalence was $23 \%$ [11]. This increased prevalence could be explained by multiple factors. The main determinants of pul- monary arterial pressure are cardiac output, pulmonary vascular resistance and pulmonary capillary wedge pressure [27]; all these factors can be altered at a variable extent in CKD patients. Thus, an increase in cardiac output due to hyperdynamic circulation secondary to AVF, anemia 
[28] and volume overload affects some of the CKD patients [29]. Our study shows a significantly higher prevalence of AVF in PH patients as well as a higher concentration of Nt-Pro-BNP this fact could reflect a high prevalence of left ventricular dysfunction in this population but also, could be a volume status marker. However we did not found any difference in the hemoglobin levels or epoetin usage between both groups of patients.

Pulmonary vascular resistance can be affected by 3 factors: first, endothelial dysfunction and production of vasoactive molecules from the endothelium in uremic milieu [30, 31]. Among other molecules, asymmetric dimethylarginine (ADMA) and endothelin-1, are found in high concentrations in CKD patients [32,33]; ADMA is an endogenous inhibitor of vasodilator effect of nitric oxide while endothelin-1 is a potent vasoconstrictor. Both molecules may play an important role increasing systemic and pulmonary vascular resistance. In this study, we have not measured these laboratory parameters. Second, vascular calcification in CKD is not always restricted to systemic circulation; it can also affect the pulmonary tree [34]. Animal studies suggest that prolonged exposure to PTH effects induces pulmonary vascular calcification, which is manifested by decreased diffusing capacity and vascular compliance, alterations that can reverse after parathyroidectomy [35]. However, in our study, we did not find differences in calcium, phosphorus or PTH concentration between both groups. Similar findings were reported by Amin et al. [36] in $15 \mathrm{HD}$ patients, in which they also analyzed the degree of pulmonary vascular calcification by technetium ${ }^{99}$ diphosphate-marked scintigraphy; they however did not find significant differences between patients with and without $\mathrm{PH}$.

Finally, pulmonary capillary wedge pressure is mainly determined by the filling pressure in the left heart chambers, which is influenced by systolic and diastolic dysfunction, both conditions being highly prevalent among CKD patients [37]. In our study, we found a higher prevalence of systolic and diastolic dysfunction among $\mathrm{PH}$ patients, highlighting the main role that this entity may have in the development of $\mathrm{PH}$.

Recent studies have shown that end-stage renal disease patients with $\mathrm{PH}$ have worse prognosis than patients without $\mathrm{PH}[2,3,6,38,39]$. Our study in non-dialysisdependent CKD patients confirms that the presence of $\mathrm{PH}$ is an independent predictor of $\mathrm{CV}$ events and mortality, besides being a direct consequence of other diseases that are also predictors of mortality (systolic dysfunction, diastolic dysfunction, etc.). After the statistical adjustment for these variables, $\mathrm{PH}$ maintains its predictive val- ue of mortality and morbidity; therefore, it appears that $\mathrm{PH}$ itself, regardless of etiology, plays an important role in the prognosis of CKD patients. In addition to the mechanical effect of chronic increased pressure in the pulmonary vascular tree on right ventricular function, there is evidence that diffusion of carbon dioxide is significantly lower in HD patients, probably as a result of some degree of subclinical pulmonary edema. Indeed, ultrafiltration can improve the ventilation/perfusion ratio [40].

Our study has some limitations. First, we have only estimated the PASP by echocardiography, instead of measuring it directly by RHC. Because of its invasive nature, as far as we know to date, only one study has been reported in which the PASP was measured using RHC [5]. Most of studies use the estimate PASP by transthoracic echocardiography because of its noninvasive nature and the good correlation with RHC $[14,15]$. Second, no other information about volume status or body composition analysis by bioimpedance was collected.

We conclude that $\mathrm{PH}$ is a common finding in CKD, and its prevalence becomes higher as renal disease progresses. The main predictors of $\mathrm{PH}$ are, age, loss of renal function, history of CV events, the presence of an AVF and left ventricular dysfunction. $\mathrm{PH}$ is also a valuable predictor of mortality and CV events. Doppler echocardiography is a useful tool to identify patients at risk. Further studies are needed to assess whether the early intervention on risk factors (e.g. fluid overload) could improve patients' outcomes.

\section{Acknowledgements}

This research was partially supported by a grant of the College of Physicians of Castellón, Spain.

\section{Disclosure Statement}

The authors declare that they have no conflict of interest.

References

1 Bolignano D, Rastelli S, Agarwal R, Fliser D, Massy Z, Ortiz A, Wiecek A, MartinezCastelao A, Covic A, Goldsmith D, Suleymanlar G, Lindholm B, Parati G, Sicari R, Gargani L, Mallamaci F, London G, Zoccali C: Pulmonary hypertension in CKD. Am J Kidney Dis 2013;61:612-622.

2 Agarwal R: Prevalence, determinants and prognosis of pulmonary hypertension among hemodialysis patients. Nephrol Dial Transplant 2012;27:3908-3914. 
3 Reque J, Quiroga B, Ruiz C, Villaverde MT, Vega A, Abad S, Panizo N, Lopez-Gomez JM: Pulmonary hypertension is an independent predictor of cardiovascular events and mortality in haemodialysis patients. Nephrology (Carlton) 2016;21:321-326.

4 Hoeper MM, Bogaard HJ, Condliffe R, Frantz R, Khanna D, Kurzyna M, Langleben D, Manes A, Satoh T, Torres F, Wilkins MR, Badesch DB: Definitions and diagnosis of pulmonary hypertension. J Am Coll Cardiol 2013;62(25 suppl):D42-D50.

5 Pabst S, Hammerstingl C, Hundt F, Gerhardt T, Grohe C, Nickenig G, Woitas R, Skowasch D: Pulmonary hypertension in patients with chronic kidney disease on dialysis and without dialysis: results of the PEPPER-study. PLoS One 2012;7:e35310.

6 Yigla M, Fruchter O, Aharonson D, Yanay N, Reisner SA, Lewin M, Nakhoul F: Pulmonary hypertension is an independent predictor of mortality in hemodialysis patients. Kidney Int 2009;75:969-975.

7 Kiykim AA, Horoz M, Ozcan T, Yildiz I, Sari $S$, Genctoy G: Pulmonary hypertension in hemodialysis patients without arteriovenous fistula: the effect of dialyzer composition. Ren Fail 2010;32:1148-1152.

8 Tarrass F, Benjelloun M, Medkouri G, Hachim K, Benghanem MG, Ramdani B: Doppler echocardiograph evaluation of pulmonary hypertension in patients undergoing hemodialysis. Hemodial Int 2006; 10:356359.

9 Etemadi J, Zolfaghari H, Firoozi R, Ardalan MR, Toufan M, Shoja MM, Ghabili K: Unexplained pulmonary hypertension in peritoneal dialysis and hemodialysis patients. Rev Port Pneumol 2012;18:10-14.

10 Unal A, Sipahioglu M, Oguz F, Kaya M, Kucuk H, Tokgoz B, Buyukoglan H, Oymak $\mathrm{O}$, Utas C: Pulmonary hypertension in peritoneal dialysis patients: prevalence and risk factors. Perit Dial Int 2009;29:191-198.

11 Bolignano D, Lennartz $\mathrm{S}$, Leonardis $\mathrm{D}$, D’Arrigo G, Tripepi R, Emrich IE, Mallamaci F, Fliser D, Heine G, Zoccali C: High estimated pulmonary artery systolic pressure predicts adverse cardiovascular outcomes in stage 2-4 chronic kidney disease. Kidney Int 2015;88:130-136.

12 Task Force for Diagnosis and Treatment of Pulmonary Hypertension of European Society of Cardiology (ESC); European Respiratory Society (ERS); International Society of Heart and Lung Transplantation (ISHLT), Galie N, Hoeper MM, Humbert M, Torbicki A, Vachiery JL, Barbera JA, Beghetti M, Corris $\mathrm{P}$, Gaine S, Gibbs JS, Gomez-Sanchez MA, Jondeau G, Klepetko W, Opitz C, Peacock A, Rubin L, Zellweger M, Simonneau G: Guidelines for the diagnosis and treatment of pulmonary hypertension. Eur Respir J 2009;34 1219-1263.

13 Forfia PR, Vachiery JL: Echocardiography in pulmonary arterial hypertension. Am J Cardiol 2012;110(6 suppl):16S-24S.
14 Currie PJ, Seward JB, Chan KL, Fyfe DA, Hagler DJ, Mair DD, Reeder GS, Nishimura RA, Tajik AJ: Continuous wave Doppler determination of right ventricular pressure: a simultaneous Doppler-catheterization study in 127 patients. J Am Coll Cardiol 1985;6: 750-756.

15 Lanzarini L, Fontana A, Lucca E, Campana C, Klersy C: Noninvasive estimation of both systolic and diastolic pulmonary artery pressure from Doppler analysis of tricuspid regurgitant velocity spectrum in patients with chronic heart failure. Am Heart J 2002;144:10871094.

16 Aduen JF, Castello R, Daniels JT, Diaz JA, Safford RE, Heckman MG, Crook JE, Burger CD: Accuracy and precision of three echocardiographic methods for estimating mean pulmonary artery pressure. Chest 2011;139:347352.

17 Howard LS, Grapsa J, Dawson D, Bellamy M, Chambers JB, Masani ND, Nihoyannopoulos P, Simon R Gibbs J: Echocardiographic assessment of pulmonary hypertension: standard operating procedure. Eur Respir Rev 2012;21:239-248.

18 Levey AS, Bosch JP, Lewis JB, Greene T, Rogers N, Roth D: A more accurate method to estimate glomerular filtration rate from serum creatinine: a new prediction equation. Modification of Diet in Renal Disease Study Group. Ann Intern Med 1999;130: 461-470.

19 James PA, Oparil S, Carter BL, Cushman WC, Dennison-Himmelfarb C, Handler J, Lackland DT, LeFevre ML, MacKenzie TD, Ogedegbe O, Smith SC Jr, Svetkey LP, Taler SJ, Townsend RR, Wright JT Jr, Narva AS, Ortiz E: 2014 evidence-based guideline for the management of high blood pressure in adults: report from the panel members appointed to the Eighth Joint National Committee (JNC 8). JAMA 2014;311:507-520.

20 Yock PG, Popp RL: Noninvasive estimation of right ventricular systolic pressure by Doppler ultrasound in patients with tricuspid regurgitation. Circulation 1984;70:657-662.

21 Rudski LG, Lai WW, Afilalo J, Hua L, Handschumacher MD, Chandrasekaran K, Solomon SD, Louie EK, Schiller NB: Guidelines for the echocardiographic assessment of the right heart in adults: a report from the American Society of Echocardiography endorsed by the European Association of Echocardiography, a registered branch of the European Society of Cardiology, and the Canadian Society of Echocardiography. J Am Soc Echocardiogr 2010;23:685-713; quiz 786-788.

22 Lam CS, Borlaug BA, Kane GC, Enders FT, Rodeheffer RJ, Redfield MM: Age-associated increases in pulmonary artery systolic pressure in the general population. Circulation 2009;119:2663-2670.

23 Anderson JL, Adams CD, Antman EM, Bridges CR, Califf RM, Casey DE Jr, Chavey WE 2nd, Fesmire FM, Hochman JS, Levin TN, Lincoff AM, Peterson ED, Theroux P,
Wenger NK, Wright RS, Jneid H, Ettinger SM, Ganiats TG, Philippides GJ, Jacobs AK, Halperin JL, Albert NM, Creager MA, DeMets D, Guyton RA, Kushner FG, Ohman EM, Stevenson W, Yancy CW: 2012 ACCF/AHA focused update incorporated into the ACCF/ AHA 2007 guidelines for the management of patients with unstable angina/non-ST-elevation myocardial infarction: a report of the American College of Cardiology Foundation/ American Heart Association Task Force on Practice Guidelines. J Am Coll Cardiol 2013; 61:e179-e347.

24 Pecoits-Filho R, Bucharles S, Barberato SH: Diastolic heart failure in dialysis patients: mechanisms, diagnostic approach, and treatment. Semin Dial 2012;25:35-41.

25 Devereux RB, Savage DD, Drayer JI, Laragh $\mathrm{JH}$ : Left ventricular hypertrophy and function in high, normal, and low-renin forms of essential hypertension. Hypertension 1982;4: 524-531.

26 Strange G, Playford D, Stewart S, Deague JA, Nelson H, Kent A, Gabbay E: Pulmonary hypertension: prevalence and mortality in the Armadale echocardiography cohort. Heart 2012;98:1805-1811.

27 Sise ME, Courtwright AM, Channick RN Pulmonary hypertension in patients with chronic and end-stage kidney disease. Kidney Int 2013;84:682-692.

28 Stauffer ME, Fan T: Prevalence of anemia in chronic kidney disease in the United States. PLoS One 2014;9:e84943.

29 Tsai YC, Tsai JC, Chen SC, Chiu YW, Hwang SJ, Hung CC, Chen TH, Kuo MC, Chen HC: Association of fluid overload with kidney disease progression in advanced CKD: a prospective cohort study. Am J Kidney Dis 2014; 63:68-75.

30 Thambyrajah J, Landray MJ, McGlynn FJ, Jones HJ, Wheeler DC, Townend JN: Abnormalities of endothelial function in patients with predialysis renal failure. Heart 2000;83: 205-209.

31 van Guldener C, Lambert J, Janssen MJ, Donker AJ, Stehouwer CD: Endothelium-dependent vasodilatation and distensibility of large arteries in chronic haemodialysis patients. Nephrol Dial Transplant 1997;12(suppl 2):14-18.

32 Brooks DP: Role of endothelin in renal function and dysfunction. Clin Exp Pharmacol Physiol 1996;23:345-348.

33 Vallance P, Leone A, Calver A, Collier I, Moncada S: Accumulation of an endogenous inhibitor of nitric oxide synthesis in chronic renal failure. Lancet 1992;339:572-575.

34 Jarava C, Marti V, Gurpegui ML, Merello JI, Rdez-Quesada B, Palma A: Pulmonary calcification in chronic dialysis patients. Nephrol Dial Transplant 1993;8:673-674.

35 Akmal M, Barndt RR, Ansari AN, Mohler JG Massry SG: Excess PTH in CRF induces pulmonary calcification, pulmonary hypertension and right ventricular hypertrophy. Kidney Int 1995;47:158-163. 
36 Amin M, Fawzy A, Hamid MA, Elhendy A: Pulmonary hypertension in patients with chronic renal failure: role of parathyroid hormone and pulmonary artery calcifications. Chest 2003;124:2093-2097.

37 Shara NM, Wang H, Mete M, Al-Balha YR, Azalddin N, Lee ET, Franceschini N, Jolly SE, Howard BV, Umans JG: Estimated GFR and incident cardiovascular disease events in
American Indians: the Strong Heart Study. Am J Kidney Dis 2012;60:795-803.

38 Li Z, Liu S, Liang X, Wang W, Fei H, Hu P, Chen Y, Xu L, Li R, Shi W: Pulmonary hypertension as an independent predictor of cardiovascular mortality and events in hemodialysis patients. Int Urol Nephrol 2014;46:141-149.

39 Ramasubbu K, Deswal A, Herdejurgen C, Aguilar D, Frost AE: A prospective echocar- diographic evaluation of pulmonary hypertension in chronic hemodialysis patients in the United States: prevalence and clinical significance. Int J Gen Med 2010;3:279-286.

40 Romaldini H, Rodriguez-Roisin R, Lopez FA, Ziegler TW, Bencowitz HZ, Wagner PD: The mechanisms of arterial hypoxemia during hemodialysis. Am Rev Respir Dis 1984;129:780784 